https://helda.helsinki.fi

Sports pushes the limits of gender

\title{
Vuorio, Lotta
}

2020-05

Vuorio , L 2020 , ' Sports pushes the limits of gender ', Tijdschrift voor Genderstudies, vol. 23 , no. 1 , pp. 85-89 . https://doi.org/10.5117/TVGN2020.1.007.VUOR

http://hdl.handle.net/10138/326892

https://doi.org/10.5117/TVGN2020.1.007.VUOR

acceptedVersion

Downloaded from Helda, University of Helsinki institutional repository.

This is an electronic reprint of the original article.

This reprint may differ from the original in pagination and typographic detail.

Please cite the original version. 


\section{Recension}

Tijdschrift voor G enderstudies / The Dutch J ournal for G ender Studies Lotta Vuorio

\section{Book details}

Building Bodies - Transnational Historical Approaches to Sport, Gender and Ethnicities

ISBN-13: 978-9087047566

ISBN-10: 9087047568

\section{Sports pushes the limits of gender}

The Players Tribune

Building

Bodies: Transnational Historical Approaches to Sport, Gender and Ethnicities 


Historical Social Research

Physical Culture

Building Bodies 
A bout the author

\section{L otta V uorio}

\section{References}

Gender Trouble: Feminism, and the Subversion of identity

Historical Social Research

M egan Rapinoe reaction to - The Best FIF A Women's Player 2019

The Players' Tribune 